\title{
Eva Stehlíková (1. 2. 1941 Plzeň - 12. 8. 2019 Brno)
}

\author{
Karolína Stehlíková
}

\begin{abstract}
Absolvovala střední jedenáctiletou školu v Děčíně (maturita 1958). V Praze vystudovala obory latina a čeština na Filozofické fakultě UK. V roce 1969 zde získala titul PhDr. v oboru antické literatury - česká literatura za disertační práci Antika v české poezii a dramatě po roce 1945. Na FF UK externě přednášela o antickém divadle a učila latinský jazyk (1963-1966, tzv. asistentské triennium). Mezi lety 1966-1998 působila jako vědecko-technická (po roce 1989 jako vědecká) pracovnice v Ústavu pro klasická studia v Akademii věd České republiky (původně Kabinet pro studia řecká, římská a latinská Československé akademie věd). Pracovala zde na dlouhodobých úkolech - Slovnik středověké latiny, Bibliografiie českých a latinských studii v Československu či kolektivní monografie Antika a česká kultura. Podílela se také na vydávání tří časopisů Listy filologické, Eirene a Zprávy Jednoty klasických filologů. Nové poměry po roce 1989 využila k radikální proměně antického oddělení, které se původně specializovalo na historii antického Řecka a Říma. Stehlíková kolem sebe soustředila badatele věnující se tradici antického divadla v novověké české kultuře, čímž určila současný profil tohoto oddělení v Kabinetu pro klasická studia Filosofického ústavu Akademie věd, jak se dnes tato instituce jmenuje. Stála u zrodu on-line databáze inscenací antického dramatu (viz www.olympos.cz) a iniciovala propojení antického oddělení s Katedrou divadelní vědy Filozofické fakulty Univerzity Karlovy. Navázala také spolupráci s European Network of Research and Documentation of Performances of Ancient Greek Drama.

V letech 1977-1981 vydávala s kritikem a dramaturgem Václavem Königsmarkem samizdatový časopis Dialog. V roce 1988 externě vyučovala na Katedře divadelní a filmové vědy FF UK. V roce 1994 se habilitovala na Masarykově univerzitě (habilitační práce Řecké a římské divadlo) a zahájila své pedagogické a vědecké působení na Katedře divadelních studií (v té době Ústav divadelní a filmové vědy) na Filozofické fakultě Masarykovy univerzity, kde přednášela s přestávkou do roku 2017. V roce 1998 byla jmenována profesorkou. Mezi lety 1998-2006 působila také na Katedře divadelní vědy na FF UK. $\mathrm{V}$ roce 2017 se stala emeritní profesorkou Masarykovy univerzity.
\end{abstract}


Ve své vědecké práci se věnovala antickému a středověkému divadlu, intertextuálním vztahům (antické tradice v literatuře, divadle a filmu), moderním inscenacím antického dramatu a českému divadlu 60. let (Laterna magika, Alfréd Radok). Coby mezinárodně uznávaná znalkyně antického divadla pomohla české divadelní vědě zprostředkovat kontakty se zahraničními univerzitami a vědeckými pracovišti.

Za svého profesního života absolvovala řadu zahraničních stáží (1989 Ženeva, Fondation Hard, 1991 a 1993 Londýn, British Academy London, 1993 a 1996 Istituto Papyrologico Firenze, 1995 Österreichisches Ost- und Südost Europa- Institut Wien, 1998 Clare Hall Cambridge, 2001 Onassisovo stipendium Řecko). Přednášela také v zahraničí (Kraków, Nikosia, Firenze, Oxford, Athény, Toronto, Coimbra, Warwick University, Epidauros). Byla řešitelkou několika vědeckých úkolů (Ve znamení Shakespeara - Fond rozvoje vysokých škol 1997, Inscenace antických dramatiků na českých scénách - GAČR 1998-2000, Alfréd Radok - GAČR 2000-2003). Mezi lety 2009 a 2014 byla šéfredaktorkou časopisu Theatralia: revue současného myšleni o divadelni kultuře.

Věnovala se rovněž překladatelské a popularizační činnosti. Z latiny přeložila např́íklad Senekovy tragédie Faidra a Král Oidipus či Plautovu Komedii o laně, ze starořečtiny Menandrovy komedie a Euripidovu tragédii Trójanky. S Karlem Hubkou a Josefem Topolem se podílela na překladu Euripidovy tragédie Ifigenie v Aulidě. Připravila řadu pořadů pro Český rozhlas. Od roku 1965 spolupracovala s inscenačními týmy při uvádění antických her (odborné konzultace, texty do programů). Za svou činnost získala v roce 1994 Cenu Akademie věd České republiky za popularizaci vědy. V roce 2012 byla nominována na Cenu Milady Paulové.

Je autorkou šesti monografických prací Řecké divadlo klasické doby (1991), Římské divadlo (1993), Antické divadlo (2005, anglický překlad Ancient Greek and Roman Theatre 2014), A co když je to divadlo? (1998), Divadlo za časů Nerona a Seneky (2006), Co je nám po Hekubě (2012) a výboru ze starších studií Vetera et nova (2014). Edičně a spoluautorsky se podílela na knize Alfréd Radok mezi filmem a divadlem (2007). Iniciovala souborné vydání Senecových tragédií (2017, 2018), na kterém se i překladatelsky podílela. Edičně připravila také dva výbory antické poezie (Catullus. Zahořklé polibky, 1980, Sbohem starý Řime, 1983).

Jejím manželem byl klasický filolog a lingvista Karel Hubka (1937-1986). Žila postupně ve Starém Plzenci, Děčíně, Praze a Brně.

Sestaveno na základě různých zdrojů a za spolupráce Jana Bažanta. 